\title{
PERAN KELOMPOK WANITA TANI DALAM MENINGKATKAN KESEJAHTERAAN MASYARAKAT MELALUI PEMANFAATAN LAHAN KECIL
}

\section{THE ROLE OF WOMEN'S FARMERS GROUP IN IMPROVING THE COMMUNITY WELFARE THROUGH THE UTILIZATION OF SMALL LAND}

\author{
${ }^{1)}$ Muhammad Nasir, ${ }^{2}$ Selamat Riadi, ${ }^{3}$ Halim Simatupang, ${ }^{4}$ Pasca Dwi Putra \\ ${ }^{1}$ Jurusan Pendidikan Akuntansi, ${ }^{2}$ Jurusan Pendidikan Teknik Mesin, \\ ${ }^{3}$ Jurusan Pendidikan Biologi, ${ }^{4}$ Jurusan Pendidikan Bisnis \\ Universitas Negeri Medan \\ Jalan Willem Iskandar, Pasar V - Kotak Pos No. 1589 Medan 20221 \\ email: nasir@unimed.ac.id
}

\begin{abstract}
ABSTRAK
Peran serta perempuan dalam menciptakan kesejahteraan sangatlah penting. Tujuan dari kegiatan ini adalah memberikan pendampingan dan penyuluhan dari aspek ekonomi, teknologi dan biologi. Materi kegiatan berupa penyusunan harga pokok produksi dan kewirausahaan, penggunaan teknologi tepat guna, serta variasi tanaman dataran tinggi didataran rendah serta metode penanamannya. Hasil dari kegiatan ini dapat memberikan pengetahuan ketrampilan kepada mitra tentang konsep dasar kewirausahaan dan keuangan dalam usaha mikro, efisiensi pengelolaan usaha melalui penggunaan teknologi tepat guna, serta pengetahuan jenis tanaman dataran tinggi lainnya yang dapat ditanam pada dataran rendah. Kegiatan ini memberikan manfaat bagi masyarakat dalam mengurangi ketergantungan tanaman dataran tinggi dalam memenuhi kebutuhan sayur serta meningkatkan peran wanita dalam pembangunan nasional.
\end{abstract}

Kata kunci : Kesejahteraan, Kelompok Wanita Tani, Kewirausahaan, Teknologi Tepat Guna

ABSTRACT

Women's participation in creating prosperity is very important. The purpose of this activity is to provide assistance and counseling from aspects of economics, technology and biology. The activity material is in the formulation of the cost of production and entrepreneurship, the use of appropriate technology, and variations in the highland lowland plants and the method of planting. The results of this activity can provide skills knowledge to partners about the basic concepts of entrepreneurship and finance in microenterprises, efficiency of business management through the use of appropriate technology, and knowledge of other highland plant species that can be planted in the lowlands. This activity provides benefits to the community in reducing dependence on upland plants in meeting vegetable needs and increasing the role of women in national development.

Keywords: Welfare, Farmer Women Group, Entrepreneurship, Appropriate Technology

Submited : 2 September $2018 \quad$ Revision : 17 Desember 2018 Accepted : 1 Januari 2019

\section{PENDAHULUAN}

Peran perempuan dalam pembangunan nasional sangatlah penting. Hal ini dilihat dari partisipasi perempuan dalam memajukan pertumbuhan ekonomi. Disamping itu, peran perempuan sangat mendukung suatu pembangunan yang berkeadilan serta membangun desa. (Manembo, 2017). Sekarang ini perempuan tidak hanya bekerja sebagai ibu rumah tangga saja tetapi dapat menduduki suatu jabatan dan tingkatan yang lebih tinggi serta berkontribusi terhadap kesejahteraan masyarakat (Prabosiwi, 2015). Salah 
satunya di Desa Padang Cermin Kecamatan Selesai Kabupaten Langkat. Desa Padang Cermin memiliki luas 14,56 $\mathrm{km}^{2}$ dengan luas lahan pertanian 1.053 ha (langkat.bps.go.id). Desa Padang Cermin memiliki jumlah penduduk sebesar 10.021 dengan perbandingan berdasarkan jenis kelamin yaitu 5.056 berjenis kelamin lakilaki dan 4.965 berjenis kelamin perempuan. Adapun jumlah ini hampir seimbang. Tetapi sebagian besar penduduk yang bekerja merupakan laki-laki sedangkan perempuan banyak bekerja sebagai ibu rumah tangga. Adapun pekerjaan utama laki-laki pada desa ini adalah petani yaitu menanam padi dan sayuran. Sebelumnya, Indonesia merupakan negara agraria yang mata pencaharian penduduknya adalah petani. Hal ini didukung oleh Basrowi dan Juariyah (2010) yang berpendapat bahwa penduduk Indonesia sebagian merupakan penduduk pedesaan yang merupakan ciri dari negara agraris yang bermata pencaharian bertani. Adapun tanaman yang menjadi prioritas adalah padi dan sayuran Disamping itu, dalam bertani membutuhkan lahan yang cukup luas agar diperoleh hasil yang lebih maksimal.

Tetapi sekarang ini, lahan pertanian didesa ini sudah mulai mengalami penyempitan dikarenakan beralih fungsi pada tanaman perkebunan seperti karet dan sawit. Petani kesulitan untuk bercocok tanam khususnya padi dan sayuran. Oleh karena itu, petani sekarang ini memanfaatkan lahan sekecil mungkin dalam bercocok tanam (Dwiratna, Widyasanti, \& Rahmah, 2017, Kesumawati, Hayati, \& Thamrin, 2012, Purwantini 2016). Dengan adanya lahan yang kecil, petani tidak memperoleh hasil yang maksimal sehingga mengalami penurunan pendapatan. Berkurangnya pendapatan yang diperoleh suami dalam membiayai rumah tangga maka perempuan pada desa ini yang bergabung pada Kelompok Wanita Tani (KWT) Kamboja untuk memanfaatkan lahan yang terbatas pada halaman rumah yang mereka miliki untuk membantu dalam membiayai rumah tangga. Adapun tujuan dibentuknya KWT ini untuk menyelesaikan permasalahan keterbatasan lahan pertanian yang sudah beralih fungsi, pemanfaatan lahan yang belum terpakai pada daerah rumah mereka, serta membantu meringankan pembiayaan rumah tangga sehingga pada akhirnya meningkatkan kesejahteraan masyarakat. Disamping itu, adanya KWT ini sebagai wadah dalam berkreativitas dan berinovasi terhadap teknologi pertanian yang dapat diaplikasikasi pada masyarakat desa.

Adapun kegiatan yang dilakukan yaitu menanam sayuran yang seharusnya ditanam pada dataran tinggi ditanam pada dataran rendah secara organik. Selama ini masyarakat sangat bergantung pada sayuran yang ditanam pada dataran tinggi sehingga sayuran menjadi sedikit langka dikarenakan daerah desa yang cukup jauh dari kota. Disamping itu, harga yang cukup mahal dikarenakan jarak distribusi yang cukup jauh, sayuran dari pegunungan juga mengandung zat yang kurang baik bagi tubuh. Oleh karena itu, untuk mengatasi permasalahan tersebut masyarakat Desa Padang Cermin khususnya perempuan membentuk suatu kelompok untuk mencoba menanam sayuran yang berasal dari dataran tinggi untuk ditanam pada dataran rendah. Penanaman tanaman dataran tinggi didataran rendah bukan merupakan hal yang baru. Banyak tanaman dataran tinggi dapat ditanam pada dataran rendah dengan teknik atau metode penanamn khusus ( Kesumawati, Hayati, \& Thamrin, 2012)

Ide penanaman ini dikarenakan untuk mengurangi ketergantungan sayuran yang berasal dari dataran tinggi yang memiliki harga jual yang lebih mahal dikarenakan letak desa yang cukup jauh dari kota. Sayuran tersebut juga menggunakan pupuk kimia yang memiliki 
dampak negatif terhadap kesehatan sehingga adanya ide penanaman sayuran dataran tinggi ini juga sebagai pemanfaatan kotoran hewan ternak masyarakat setempat seperti lembu dan kambing sebagai pupuk alami dan organik. Disamping itu, sebagai pemanfaatan lahan kosong yang terdapat didepan pemukiman penduduk serta membantu perekonomian keluarga. Tetapi dalam menjalankan kegiatan ini, terdapat permasalahan yang dihadapi mitra seperti belum adanya penggunaan teknologi tepat guna dalam membantu menyelesaikan pekerjaan mereka, anggota KWT yang sebagian besar hanya tamatan SMA sehingga memiliki keterbatasan pengetahuan mengenai tanaman dataran tinggi dan teknik penanamannya, pengetahuan kewirausahaan khususnya pemasaran dan pengetahuan dalam menghitung harga pokok produksi.

Permasalahan yang dihadapi pertama yaitu belum adanya penggunaan teknologi tepat guna dalam membantu melaksanakan kegiatan. Selama ini mitra bekerja secara manual seperti mengelola dan menyiram lahan secara manual. Butuh waktu yang cukup lama jika dilakukan secara manual sehingga diperlukan penggunaan teknologi dalam mempermudah kegiatan. Seperti bantuan alat penyiram tanaman. Selama ini mitra menyiram sayuran secara manual yaitu dengan menggunakan alat penyiram yang diisi dari sumur mitra kemudian dibawa secara manual kemudian disiram ke tanaman. Cara ini membutuhkan waktu yang cukup lama dan harus dilakukan berulang kali pada pagi dan sore agar sayuran tidak layu. Sehingga sangat diperlukan penggunaan teknologi dalam membantu kegiatan mitra. Pentingnya teknologi tepat guna pada masyarakat desa sangat membantu dalam menyelesaikan kegiatannya yang selama ini dilakukan secara manual serta diharapkan meningkatkan produktivitasnya (Sukardi 1994 ; Lakitan dan Gofar, 2013).
Permasalahan yang berikutnya masih terbatasnya pengetahuan mitra mengenai tanaman dataran tinggi yang dapat ditanam dan teknik penanamannya. Ini menjadi alasan hasil yang didapatkan kurang maksimal sehingga diperlukan pengetahuan mengenai tanaman dataran tinggi dan teknik penanamannya. Penyuluhan ini akan membantu mitra dalam mengembangkan usahanya dengan mengembangkan usahanya kedepan menjadi lebih baik.

Permasalahan lainnya yaitu berkaitan dengan ekonomi. Sebagian besar anggota KWT hanya pada tingkat pendidikan SMA sehingga kurang memiliki ketrampilan dalam bidang pertanian dan kewirausahaan. Adapun dalam bidang kewirausahaan seperti masih kurang pengetahuan dan ketrampilan pemasaran serta keuangan. Produk hanya dijual disekitar desa atau hanya dikonsumsi pribadi sehingga belum adanya keberlanjutan usaha. Menurut Jong \& Wenekers (2018) bahwa pentingnya kewirausahaan membantu melihat peluang untuk menciptakan sesuatu yang baru dengan mengambil risiko melalui pendekatan inovatif dan menjadikan usaha yang mandiri dalam menghadapi pesaing Disamping itu, kurangnya pengetahuan masyarakat dalam bidang keuangan menyebabkan mitra kesulitan menentukan harga jual yang wajar dari produk tersebut. Mitra hanya memperkirakan harga jual didasarkan apa yang mereka lakukan tanpa memperhitungkan biaya yang mereka keluarkan sehingga tidak mengetahui apakah mereka memperoleh keuntungan atau tidak. Hal ini didukung dengan pendapat Putra, Efendi, \& Brata, (2018) bahwa manajemen keuangan dan kewirausahaan berperan penting dalam merencanakan dan mengembangkan usaha menjadi lebih baik yang berdampak terhadap kesejahteraan masyarakat. Disamping itu, pengetahuan perencanaan keuangan oleh mitra akan membantu 
dalam mengembangkan usaha menjadi lebih baik (Linawati dan Restuti, 2015 ; Anggraeni, 2016)

Harapan dari kegiatan ini dapat mengembangkan usaha menjadi lebih besar dan mensejahterakan penduduk di Desa Padang Cermin Kecamatan Selesai Kabupaten Langkat Provinsi Sumatera Utara.

\section{METODE}

Kegiatan ini dilakukan bersama dengan Kelompok Wanita Tani (KWT) Kamboja sebagai wadah untuk menyalurkan pengetahuan dan ketrampilan di Desa Padang Cermin Kecamatan Selesai Kabupaten Langkat. Adapun metode yang diberikan berupa pendampingan dan penyuluhan mengenai penggunaan teknologi tepat guna untuk membantu mitra dalam mengembangkan usaha, pendampingan dan penyuluhan mengenai tanaman dataran tinggi dan teknik penanamannya, serta penyuluhan dan pendampingan mengenai kewirausahaan dan menghitung harga pokok produksi.

\section{HASIL DAN PEMBAHASAN}

\section{Pendampingan dan Penyuluhan Penggunaan Teknologi Tepat Guna}

Adapun permasalahan pertama yang dihadapi mitra adalah belum adanya penggunaan teknologi tepat guna yang membantu mitra dalam menjalankan kegiatannya. Salah satunya dalam menyiram bunga dimana mitra menggunakan alat penyiram bunga manual dengan mengambil air disumur kemudian membawanya ketanaman untuk disiram secara manual. Hal ini menyebabkan banyak waktu yang terbuang dan membutuhkan tenaga yang ekstra. Oleh sebab itu, diberikan teknologi dalam menyiram bunga. Adapun teknologi yang diberikan berupa alat penyiram bunga yang membantu mengairin air ke seluruh sayuran tanpa harus mitra berulang kali untuk mengisi air. Terlebih dahulu, tim melakukan koordinasi dan pemetaan jalan air sehingga air yang disiramkan merata keseluruh tanaman. Setelah dilakukan pemetaan maka tim memasang teknologi penyiram air dan melakukan uji coba untuk memastikan bahwa sayuran memperoleh air secara merata.

Hasil yang diperoleh dari penggunaan teknologi dalam penyiraman air ini, mitra dapat melakukan kegiatan perawatan lainnya sehingga secara langsung dapat mempermudah pekerjaan mitra dalam merawat tanaman. Setelah dilakukan evaluasi beberapa waktu dan perolehan informasi dari mitra diperoleh hasil penggunaan teknologi tepat guna sangat membantu mempermudah pekerjaan mitra dalam merawat sayuran. Hal ini dikarenakan tercukupnya air untuk sayuran sehingga sayuran tidak layu dan tumbuh subur. Pada dasarnya, jenis sayuran yang ditanam merupakan sayuran yang hidup didataran tinggi. Sehingga jika didataran rendah yang memiliki suhu yang lebih panas membutuhkan air yang cukup agar terjaga kelembapannya. Disamping itu juga dengan adanya kecukupan air ini tanaman menjadi lebih subur dan berkembang. Oleh karena itu sangat memberikan bantuan kepada mitra dalam menyelesaikan permasalahan. Hasil ini didukung oleh Sukardi (1994) dan Lakitan dan Gofar (2013) bahwa penggunaan teknologi dalam pemberdayaan masyarakat dan usaha akan meningkatkan produktivitas usaha.

\section{Pendampingan dan Penyuluhan Jenis Tanaman Dataran Tinggi dan Teknik Penanamannya}

Permasalahan berikutnya adalah kurangnya pengetahuan mitra mengenai jenis dan cara penanaman tanaman dataran tinggi sehingga dapat ditanam pada dataran 
rendah. Selama ini, mitra dalam melakukan kegiatannya didasarkan pada insting sehingga kurang memiliki dasar pengetahuan. Pentingnya pengetahuan mengenai jenis tanamanan dan teknik penanamannya akan membantu mitra untuk mengembangkan usahanya menjadi lebih baik serta meningkatkan produktivitas. Hasil ini didukung oleh Kesumawati, dkk (2012) yang menyatakan bahwa tanaman dataran tinggi dapat ditanam pada dataran rendah jika teknik dan metode serta perawatan yang intensif.

Adapun kegiatan yang dilakukan dengan memberikan penyuluhan dan pendampingan mengenai tanaman dataran tinggi. Mitra diberikan penyuluhan mengenai karakteristik dari tanaman dataran tinggi seperti kol, brokoli, tomat, cabai, dan tanaman lainnya yang dapat ditanam pada dataran rendah. Kemudian diberikan pengetahuan mengenai teknik penanamannya sehingga dapat menyesuaikan dengan iklim sekitar. Adapun secara umum teknik dalam menanam tanaman dataran tinggi didataran rendah yaitu:

1. Mempersiapkan media tanamnya. Diutamakan media tanam yang organic seperti berasal dari sampah dedaunan yang sudah menjadi tanah ataupun jerami dan campuran dari pupuk kandang yang berasal dari kotoran hewan.

2. Mempersiapkan jaring diatas tanaman sehingga sayuran tidak terkena secara langsung sinar matahari dan suhu sekitar sayuran tidak terlalu panas.

3. Lakukan penyiraman air $2 x$ sehari yaitu pada saat pagi dimana matahari belum terlalu panas dan sore hari dalam kondisi matahari sudah hampir tenggelam sehingga sayuran tidak mengalami stress.

4. Lakukan perawatan tanaman dengan membuang tanaman gulma yang dapat mengganggu pertumbuhan sayuran.
5. Pada saat memanen sebaiknya dilakukan pada pagi hari atau pada saat sore hari setelah matahari sudah hampir tenggelam yang bertujuan agar sayuran tetap segar.

Pada penyuluhan ini juga diberikan pengetahuan mengenai penggunaan pupuk yang berasal dari kotoran hewan khususnya kambing dan lembu yang memiliki banyak manfaat dan sangat menyuburkan tanaman. Disamping itu, penggunaan pupuk organis juga bermanfaat dalam menghemat biaya sehingga menjadi lebih efisien (Nugraha dan Amini, 2013). Adapun teknik pengelolaan kotoran ternak menjadi pupuk dengan cara mengumpulkan kotoran ternak kemudian dimasukkan kedalam wadah. Campurkan dengan cerami yang telah dipotong-potong beserta papaya yang telah dihaluskan. Kemudian aduk dan diamkan beberapa hari agar dapat berfermentasi menjadi pupuk. Hasilnya diberikan kepada sayuran yang telah tumbuh dan dilakukan pada pagi hari ataupun sore hari.

Hasil dari kegiatan ini berupa pengetahuan tambahan yang diperoleh oleh mitra. Dilakukan evaluasi terhadap mitra bahwa sudah mulai dilakukan persiapan untuk melakukan teknik penanaman yang dimaksud. Tahapan yang sedang berlangsung berupa pembibitan sebelum ditempatkan pada lahan. Teknik ini diharapkan dapat mengembangkan tanaman sayuran lebih produktif.

\section{Pendampingan dan Penyuluhan Keuangan dan Kewirausahaan}

Permasalahan selanjutnya berkaitan pada bidang ekonomi yaitu keuangan dan kewirausahaan. Selama ini dalam menentukan harga jual, mitra hanya mempertimbangkan usaha yang dilakukan tanpa memperhatikan biaya yang dikeluarkan. Sehingga harga jual dari 
sayuran termasuk murah dan tidak dapat bersaing dengan pasar. Disamping itu, sayuran dipasarkan hanya pada sekitar rumah saja karena belum memiliki pengetahuan mengenai kewirausahaan dan teknik pemasaran.

Adapun pendampingan dan penyuluhan yang dilakukan berupa memberikan pengetahuan mengenai perhitungan harga pokok produksi. Mitra diberikan pengetahuan bagaimana menghitung harga pokok sayuran dimulai dari perhitungan biaya yang dikeluarkan, aktivitas yang dikerjakan dan penilaian aktivitas tersebut, serta menentukan harga jual wajar dari produk yang dihasilkan. Hasil ini didukung oleh Putra, Efendi, \& Brata, (2018) dimana pentingnya perencanaan keuangan akan membantu usaha masyarakat menjadi lebih baik. Adapun hasil dari kegiatan ini, mitra dapat menentukan harga wajar yang diperjualkan ke masyarakat.

Pendampingan dan penyuluhan dalam bidang kewirausahaan yaitu berupa penyuluhan mengenai perencanaan pengembangan usaha dan teknik pemasaran. Mitra diberikan pengetahuan mengenai bagaimana merencanakan usaha dan mengembangkan sehingga usaha tersebut menjadi lebih besar. Perencanaan usaha tidak hanya dilakukan 1 tahun kedepan tetapi beberapa tahun kedepan serta apa yang akan dilakukan. Disamping itu, penyuluhan kewirausahaan lainnya yaitu mengenai teknik pemasaran yang dapat dilakukan seperti pasar apa yang dapat ditargetkan untuk pengembangan usaha serta teknik pemasaran yang dilakukan. Hasil evaluasi dari kegiatan ini, mitra sudah mulai merencanakan pengembangan usahanya melalui peningkatan variasi produk dan rencana pemasaran produk. Pentingnya perencanaan keuangan dan usaha untuk mengembangkan usaha menjadi lebih baik
(Linawati dan Restuti, 2015 ; Anggraeni 2016).

\section{SIMPULAN}

Simpulan dari kegiatan ini adalah membantu masyarakat dalam meningkatkan ketrampilan baik dalam hal produk maupun berwirausaha. Peningkatan tersebut berupa penggunaan teknologi tepat guna dalam membantu menjalankan aktivitas usaha, menambah pengetahuan mengenai tanaman dataran tinggi yang ditanam didataran rendah, menambah pengetahuan dan ketrampilan baik dalam bidang keuangan maupun kewirausahaan. Hasil dari kegiatan ini diharapkan bermanfaat baik bagi tim, mitra, dan masyarakat secara luas.

\section{DAFTAR PUSTAKA}

Anggraeni, B. D. (2016). Pengaruh tingkat literasi keuangan pemilik usaha terhadap pengeloaan keuangan. Studi kasus: UMKM Depok. Jurnal Vokasi Indonesia, 4(1).

Basrowi dan Juariyah, S. (2010). Analisis Kondisi Sosial Ekonomi dan Tingkat Pendidikan Masyarakat Desa Srigading, Kecamatan Labuhan Maringgai, Kabupaten Lampung Timur. Jurnal Ekonomi \& Pendidikan, 7(1).

Dwiratna, S., Widyasanti, A., \& Rahmah, D. M. (2017). Pemanfaatan Lahan Pekarangan Dengan Menerapkan Konsep Kawasan Rumah Pangan Lestari. Dharmakarya, 5(1).

Jong, J. D., \& Wennekers, S. (2008). Intrapreneurship; conceptualizing entrepreneurial employee behavior. Scientific Analysis of Entrepreneurship and SMEs (SCALES), Zoetermeer: EIM, 1-47. 
Kesumawati, E., Hayati, E., \& Thamrin, M. (2012). Pengaruh Naungan dan Varietas Terhadap Pertumbuhan dan Hasil Tanaman Stroberi (Fragaria sp.) di Dataran Rendah. Jurnal Agrista, 16(1), 14-21.

Lakitan, B., \& Gofar, N. (2013). Kebijakan Inovasi Teknologi Untuk Pengelolaan Lahan Suboptimal Berkelanjutan. Makalah Seminar Nasional Lahan Suboptimal (pp. 2122).

Linawati, E., \& Restuti, M. M. D. (2015). Pengetahuan Akuntansi Pelaku Usaha Mikro, Kecil Dan Menengah (UMKM) Atas Penggunaan Informasi Akuntansi. In Conference In Business, Accounting, And Management (CBAM) 2, (1), pp. 145-149).

Manembo, A. E. (2017). Peranan Perempuan Dalam Pembangunan Masyarakat Desa (Suatu Studi Di Desa Maumbi Kecamatan Kalawat Kabupaten Minahasa Utara). Jurnal Politico, 6(1).

Nugraha, S. P. \& Amini F.N. (2013). Pemanfaatan Kotoran Sapi Menjadi Pupuk Organik. Asian Journal of Innovation and Entrepreneurship, 2 (03), 193-197.

Prabosiwi, R. (2015). Perempuan dan Perannya Dalam Pembangunan Kesejahteraan Sosial. Jurnal Kajian Ilmu Administrasi Negara. 3 (1), 4156

Purwantini, T. B. (2016). Potensi dan prospek pemanfaatan lahan pekarangan untuk mendukung ketahanan pangan. Forum Penelitian Agro Ekonomi, 30 (1), 13-30.

Putra, P. D., Efendi, H., \& Brata, W. W. W. (2018). Peningkatan Pendapatan Peternak Bebek Melalui Pelatihan
Pakan Ternak Dan Kewirausahaan. JPPM (Jurnal Pengabdian dan Pemberdayaan Masyarakat), 2(1), 57-63.

Sukardi, S. (1994). Penerapan Teknologi Tepat Guna Pada Masyarakat Desa Dan Permasalahannya. Cakrawala Pendidikan.XIII (2), 1-11

Widyasanti, A., \& Rahmah, D. M. (2017). Pemanfaatan Lahan Pekarangan Dengan Menerapkan Konsep Kawasan Rumah Pangan Lestari. Jurnal Abdimas, 21(1), 75-80. 